\title{
SEX RATIO AND AGE IN PATIENTS WITH RHEUMATOID ARTHRITIS. DATA FROM A COHORT IN SOUTH-EAST ROMANIA
}

\author{
Cristina Suta ${ }^{1}$, Lucian Petcu ${ }^{2}$, Elvira Craiu ${ }^{1}$, Maria Suta $^{1}$ \\ ${ }^{1} 3 \mathrm{rd}$ Department, Ist Clinical Disciplines, Faculty of Medicine, Ovidius University, Constanta \\ ${ }^{2}$ Biophysics and Biostatistics Department, Faculty of Dentistry, Ovidius University, Constanta
}

\begin{abstract}
- Abstract
Background. Rheumatoid arthritis (RA) epidemiology is characterised by the preference of the disease for women under age of 50 , a sex ratio female:male of $\leq 3: 1$ being classically described, along with a peak for age onset between 50 and 75 years old. The relationship between female sexual hormons and susceptibility of rheumatoid arthritis is not completely understood and regional differences in the prevalence of the disease support the idea of environmental factors influence.

Aim. To evaluate demographic features of patients with rheumatoid arthritis from South-East Romania, living in the climatic, economic and ethnic profile of Constanta county.

Material and method. We included 447 patients (age $\geq 18$ ) with RA (ACR 1987 or ACR/EULAR 2010 diagnosis criteria) admitted in our Rheumatology Department - IInd Internal Medicine Clinic, Sf. Apostol Andrei Emergency Clinical County Hospital Constanta from January 2013 to December 2014. All patients agreed to participate in the study through an informed consent (approved by local ethical comittee) signed at admittion time. All patients underwent a careful clinical, biological and imagistic evaluation.

Results. Our group of patients was a rheumatoid arthritis cohort with $88.4 \%$ Caucasian, 380 women (85\%) and 67 men $(15 \%)$, with a female-male ratio ( $F: M)$ of more than $5: 1$ (5.7:1), mean age of our patients was $62.13 \pm 11.44$ years and a mean age at onset of RA of $51.71 \pm 13.67$ years, statistically different between men and women $(p<$ 0.001). Sex distribution of rheumatoid arthritis varies with actual age of the patients, significant differences being observed in extreme age categories: $<40$ years $(F: M=17: 1)$ and $>70$ years $(F: M=4.25: 1)$, age at onset, with smoking status $(F: M=2: 1)$, in early disease $(F: M=3 \cdot 6: 1)$.

Conclusions. Female:Male ratio increases impresively in RA cases with early onset ( $<45$ years), young man's hormon constellation being probably a protective factor for the disease. Patients' age, especially age at onset, seems to be the most important factor that influences sex distribution of rheumatoid arthritis.
\end{abstract}

Keywords: rheumatoid arthritis, sex ratio, age at onset

\section{BACKGROUND}

Rheumatoid arthritis (RA) epidemiology is characterised by the preference of the disease for women under age of 50, a sex ratio female: male of $\leq 3: 1$ being classically described, along with a peak for age onset between 50 and 75 years old (1). The relationship between female sexual hormons and susceptibility of rheumatoid arthritis is not completely understood, although it is demonstrated by the epidemiology of the disease and also by other evidences, such as: high risk for RA in nulipar women, pregnancy - remission of the disease association, lower risk of RA in breastfeeding women (2). An interaction between female sexual hormons, genetic factors and smoking, as an environmental factor is suggested by many clinical trials $(3,4)$. Regional differences in the prevalence of the disease support the idea of environmental factor influence (climatic conditions, industrialization and pollution, socio-economic status or life style that includes diet and smoking). For now, with few exceptions, smoking for example, the great majority of the environmental factors remain unclear, although their contribution to disease onset is highly significant. Latitude is a geographic landmark used as a surrogate for the study of environment influence, with all its component parts, on epidemiological features of rheumatoid arthritis in different areas of the world. In Europe, for example, a North-South gradient was identified, prevalence of

\section{Correspondence address:}

Cristina Suta, 3rd Department, Ist Clinical Faculty of Medicine, Ovidius University, Constanta, Rheumatology Department, IInd Internal

Medicine Clinic, Sf. Apostol Andrei Emergency Clinical County Hospital Constanta, 145 Tomis Blvd, 900591, Constanta, Romania

E-mail: cris_duminica@yahoo.com 
RA being higher in Northern countries when compared with Southern ones (5). There is also a NorthSouth gradient in The Americas which influences the age of onset and sex distribution for the disease: RA onset is 12 years earlier for Mexican patients when compared with Canadians and Mexican cohort has a higher percentage of females $(91 \%)$ versus $77 \%$ females in the Canadian cohort (6).

\section{OBJECTIVE}

The aim of our study was to evaluate demographic features of patients with rheumatoid arthritis from South-East Romania, living in the climatic, economic and ethnic profile of Constanta county. It is a initiative in the spirit of QUEST-RA programme (Quantitative Patient Questionnaire Monitoring Standard Clinical Care of Patients with Rheumatoid Arthritis) which describes similarities and differences between the characteristics of patients with RA in several countries.

\section{MATERIAL AND METHOD}

Our study included patients with RA admitted in our Rheumatology Department - IInd Internal Medicine Clinic, Sf. Spostol Andrei Emergency Clinical County Hospital Constanta from January 2013 to December 2014. All patients agreed to participate in the study through an informed consent (approved by local ethical comittee) signed at admittion time.

The study group included both patients that were already in our record and new RA cases identified during this period. Rheumatoid arthritis diagnosis was confirmed by ACR 1987 criteria and ACR/EULAR 2010 criteria. The evaluation of all these patients was done by the Rheumatoligists working in the Clinic. All data from anamnesis, clinical evaluation and paraclinical investigations (biological and imagistic) were noted down at the same date. We excluded patients with age under 18 and those with juvenile onset of the disease.

\section{STATISTICAL ANALYSIS}

Results for continuous variables are presented as mean, standard deviation, median, and percentages. Statistical significance was tested with parametric tests (One sample T test, independent samples T test, One way ANOVA) for continuous variables and the chi-square test for categorical variables. All tests were considered significant if $p<0.05$ and were done using Statistical Package for the Social Sci- ences v.20 (SPSS Inc., Chicago, USA, 2008) for Windows.

\section{RESULTS}

Our study included 447 patients with rheumatoid arthritis, with the onset of the disease during adulthood (age $\geq 18$ years). Our group of patients was a rheumatoid arthritis cohort with $88.4 \%$ Caucasian, 380 women ( $85 \%)$ and 67 men (15\%), with a femalemale ratio (F:M) of more than 5:1 (5.7:1) (Table 1).

\section{Female:Male ratio and actual age in RA patients}

Mean age of our patients was $62.13 \pm 11.44$ years: $61.55 \pm 11.56$ years, women's mean age and $65.39 \pm$ 10.22 years mean age for men included in our study group ( $\mathrm{t}=2.54, \mathrm{df}=445, \mathrm{p}=0.01)$. The youngest patient was 26 years old in female group and 39 years in male group. The oldest ones were 86 years old in both groups. Most of the patients, $67.8 \%$, were in 40-70 years group. Young patients (under age of 40) represent $4 \%$ of the study group: one man and 17 women, with a F:M ratio of $17: 1$. At the opposite side, old patients group (age over 70 years) includes $28.2 \%$ of the total number ( 24 men and 102 women with a F:M ratio of $4.25: 1$ ). Although there are big differences for F:M ratio in extreme age groups, these differences don't get statistical significance $(\mathrm{p}=0.2)$.

TABLE 1. Demographic characteristics of study patients

\begin{tabular}{|c|c|c|c|}
\hline Characteristics & $\begin{array}{c}\text { Number } \\
\text { (out of } 447- \\
\text { study group) }\end{array}$ & Percentage & $\begin{array}{c}\text { Mean with } \\
\text { standard } \\
\text { deviation }\end{array}$ \\
\hline Age (years) & & & $\begin{array}{c}62.13 \pm 11.44 \\
\text { years }\end{array}$ \\
\hline $\begin{array}{l}\text { Age at onset } \\
\text { (years) }\end{array}$ & & & $\begin{array}{c}51.71 \pm 13.67 \\
\text { years }\end{array}$ \\
\hline Women & 380 & $85 \%$ & \\
\hline Men & 67 & $15 \%$ & \\
\hline Caucasian & 395 & $88.40 \%$ & \\
\hline Urban & 357 & $79.86 \%$ & \\
\hline Rural & 319 & $71.36 \%$ & \\
\hline Non-smokers & 300 & $67.10 \%$ & \\
\hline Employee & 91 & $20.35 \%$ & \\
\hline Disease retiree & 115 & $25.72 \%$ & \\
\hline Disabled & 190 & $42.50 \%$ & \\
\hline BMI (kg/m²) & & & $27.19 \pm 5.17$ \\
\hline
\end{tabular}

Note: $B M I-$ body mass index

\section{Female:Male ratio and age at onset of RA}

In our RA cohort, the disease sets at a mean age of $51.71 \pm 13.67$ years, earlier in women $(50.56 \pm 13.74$ years $)$ and later in men $(58.19 \pm 11.38$ years $)$ with sta- 
tistical significant differences $(t=4,292, \mathrm{df}=445, \mathrm{p}<$ $0,001)$. The most frequent onsets are between 40 and 70 years old $(72.2 \%)$ with an incidence peak between 42 and 58 years old ( $47.7 \%$ of all patients). RA onsets before age of 40 were present in 87 patients (19.5\%): 3 men (3.44\%) and 83 women (95.4\%), this age interval shwoing a clear preference for RA in women with a F:M ratio of more than 25:1 (27.6:1). When late age of onset ( $\geq 70$ years) was considered, we found out that RA had a late onset in 41 out of 447 patients of the study group (9.2\%): 32 women and 9 men, with a F:M ratio of less than $4: 1$ (3.55:1).

\section{Female:Male ratio and patients' ethnicity}

The largest Tatar community in this European region lives in Constanta county (24194 Tatars according to the latest census) representing $3.3 \%$ of population living in our county. Our study group with RA patients included 52 Tatars $(11.6 \%$ out of the whole group): 9 men and 43 women with a F:M ratio less than $5: 1(4.77: 1)$. Mean age for Tatar patients with rheumatoid arthritis is $61.27 \pm 10.74$ years and mean age at onset of the disease is $49 \pm 15.12$ years $(48.07 \pm 15.79$ years for women and $53.44 \pm 11.05$ years for men). Sex distribution, mean age of the patients and mean age at onset are not influenced by ethnicity.

\section{Female:Male ratio and patients' residence}

A large proportion of our patients (357 din 447) live in the urban area (79.86\%): 58 of the 67 men in our group (86.5\%) and 299 out of the 380 women included in the study (78.7\%). 90 patients live in the country side: 81 women $(90 \%)$ and $9(10 \%)$ men with a F: M ratio of 9:1, higher than the ratio for the whole group, but not statistically significant $(p=0.1)$.

Constanta county has a riparian area and a continental one which are different from both geogaphic and economic point of view. According to our analysis, in this riparian area, much more industrialized and urbanized, live $71.4 \%$ of the patients: 54 out of the 67 men $(80.6 \%)$ and 265 of 380 women of the study group (69.7\%), F:M ratio 5:1. Female:male ration in the continental area of the county is similar with that found in the rural zone, 9:1.

\section{Female:Male ratio and smoking status}

Regarding lifestyle, $32.9 \%$ of our patients were smokers (147 patients: 47 men and 100 women) and
104 of them (23.3\%) were smoking at the onset of the disease ( 28 men, 76 women). Therefore $84 \%$ of men with RA and $26.2 \%$ of women with RA ever smoked and the great majority of them were smoking before the disease onset. Female: men (F:M) ratio decreases to 2:1 for patients who ever smoked or were smokers at onset when compared to non-smokers with RA for whom F: M ratio is 14:1 $(p<0.001)$. Smoking increases impresively the risk of the disease for smoker men versus smoker women $(\mathrm{OR}=6.58,95 \%$ CI: 3.718-11.646).

\section{Female:Male ratio in early disease (diagnosed between 2010-2014)}

Mean disease duration for our study group was $10.75 \pm 8.85$ years, $11.32 \pm 9.10$ years for women and $7.49 \pm 6.39$ years for men $(t=-3.301, d f=445$, $\mathrm{p}=0.001)$. We found 56 patients with early RA $(12.5 \%)$ with disease duration less than 1 year: 44 women $(78.6 \%)$ and 12 men $(21.4 \%)$ with a F:M ratio less than 4 (3.66:1). We found statistically significant differences for the age of onset in these cases of early disease: there is a 10 years increase for age at onset in patients with early RA $(62.57 \pm 12.23$ years) versus mean age at onset for the entire study group (51.71 \pm 13.67 years) and also when compared with the group of patients with established disease $(50.15 \pm 13.17$ years $)(p<0.001)$. There are no significant differences between men and women regarding age at onset in this early disease group (Table 2). We also found an increase of more than 10 years for age at onset in the group of RA women diagnosed in the previous 3 years and a possible decrease of RA incidence for female sex (Table 2).

TABLE 2. Early disease versus establisehd diseases and age

\begin{tabular}{|l|l|l|l|}
\hline & $\begin{array}{l}\text { Established } \\
\text { disease } \\
(\mathbf{N}=\mathbf{3 9 1})\end{array}$ & $\begin{array}{l}\text { Early disease } \\
\mathbf{( N = 5 6 )}\end{array}$ & p-value \\
\hline Actual age (years) & $61.96 \pm 11.34$ & $63.25 \pm 12.17$ & $\mathrm{p}=0.432$ \\
\hline $\begin{array}{l}\text { Age at onset (years) } \\
\text { (N=447) }\end{array}$ & $50.15 \pm 13.17$ & $62.57 \pm 12.23$ & $\mathrm{p}<0.001$ \\
\hline $\begin{array}{l}\text { Age at onset for women } \\
\text { (years) (N=380) }\end{array}$ & $\begin{array}{l}48.96 \pm 13.08 \\
(\mathrm{~N}=336)\end{array}$ & $\begin{array}{l}62.84 \pm 12.50 \\
(\mathrm{~N}=44)\end{array}$ & $\mathrm{p}<0.001$ \\
\hline $\begin{array}{l}\text { Age at onset for men } \\
\text { (years) } \\
\text { (N=67) }\end{array}$ & $\begin{array}{l}57.45 \pm 11.28 \\
(\mathrm{~N}=55)\end{array}$ & $\begin{array}{l}61.58 \pm 11.67 \\
(\mathrm{~N}=12)\end{array}$ & $\mathrm{p}=0.258$ \\
\hline $\begin{array}{l}\text { Onset-diagnosis period } \\
\text { (months) }\end{array}$ & $17.85 \pm 25.36$ & $4.09 \pm 3.73$ & $\mathrm{p}<0.001$ \\
\hline F:M Ratio & $6: 1$ & $3.6: 1$ & $\mathrm{p}=0.161$ \\
\hline
\end{tabular}

Note: values are presented as means with standard deviations; F:M-female:male 


\section{Female:Male ratio and positive autoantibodies}

Rheumatoid factor (RF) was present in 359 of our patients (80.3\%): 52 men and 307 women (no statistical differences between the groups). Anti CCP antibodies were present in 300 patients $(69.44 \%)$ out of the 432 who underwent the lab test: 45 men and 255 women. The presence of autoantibodies doesn't influence significantly F:M ratio.

\section{DISCUSSIONS}

In our study group, for an actual mean age of $62.13 \pm 11.44$ years, women represent $85 \%$, with a $\mathrm{F}: \mathrm{M}$ ratio higher than the one found in medical literature. We found similar percentages for women, more than $80 \%$, also in other clinical studies from Romania, which included unselected populations of patients with rheumatoid arthritis: $86.4 \%$ (Corina MogoŞan et al. 2010, Bucuresti) (7), 90\% (Denise Cristina Cosmescu et al. 2009, Bucuresti) (8), 90\% (Ioana Râcă et al. 2012, Craiova) (9), 87,8\% (Claudiu Popescu et al. 2013, Bucuresti)(10), which means a female:male ratio similar to our study data.

In other cohort of patients from Europe, that showed ressemblances with ours, with a large proportion of Caucasians, the percentage of female population varies from $64.3 \%$ (Irland) to $88 \%$ (Serbia) (11). In countries situated close to our area (Hungry, Serbia, Poland, Rusia), women with RA represent more than $80 \%$ of the analyzed study groups, percentage in accordance to our data (12). Hertegovina is the only region that reports a $\mathrm{F}: \mathrm{M}$ ratio of $6: 1$, higher than the one found in our study cohort (13).

On the other hand, Europe Northern countries (Finland, Sweden, Norway) have a female: male ratio of 2:1 for rheumatoid arthritis patients $(14,15$, 16). Benchmarking of two cohorts of patients with early rheumatoid arthritis from Sweden (317 patients between 1996-1998 and 467 patients between 2006-2009) showed a constant percentage of female, less than $70 \%(67.2 \%$, respectively $67.9 \%)$ in both groups with a F:M ratio of 2:1 (15). Studies performed in Norway, another Northern country, on demographic features of patients with RA showed that around $70 \%$ of them were women $(<70 \%$ in 2008$)$ with a sex ratio $F: M$ of 2:1 (16).

F:M ratio fro rheumatoid arthritis is also influenced by socio-econmic status marked by gross domestic product (GDP) of the country. A large analysis on a multinational cross-sectional cohort $(25$ countries) of demographic characteristics of RA pa- tients and of disease activity status showed a F:M ratio of 3.7:1 (75\% women) in countries with a GDP> 24,000 USD and a F:M ratio of 6.1:1 in countries with a GDP $<11,000$ USD (86\% women) (17). It looks like female: male ratio for rheumatoid arthritis patients is more influenced by GDP of a country than by the its specific geographic coordinates.

Sex distribution of rheumatoid arthritis varies with actual age of the patients as our study also shows, significant differences being observed in extreme age categories: $<40$ years $(\mathrm{F}: \mathrm{M}=17: 1)$ and $>$ 70 years $(\mathrm{F}: \mathrm{M}=4 \cdot 25: 1)$. A decrease of this ratio is also noted in other clinical studies. Rheumatoid arthritis patients registry from Oslo shows a clear change for female: male ratio according to age: more than $4: 1$ at premenopausal age and less than 2:1 after age of 60 years (18).

Data of prevalence for RA in UK also stand for a change in $\mathrm{F}$ : $\mathrm{M}$ ratio with advancing age. Thus, minimal prevalence of the disease according age and sex is: $0.12 \%$ women and $0.02 \%$ men for patients younger than 45 years (data from NOAR - Norfolk Arthritis Register - for incidence of RA in this age group which has F:M ratio of 6.45:1) versus age group over 75 years where they identified a minimal prevalence of RA for women (2.99\%) almost equal to that of male patients in the same age group (2.18\%), with a F:M ratio less than 2:1 (19).

Mean age at the onset of the disease in our study group was $51.71 \pm 13.67$ years, RA started earlier in women $(50.56 \pm 13.74$ years) and later in men $(58.19 \pm 11.38$ years $)$ with statistical significant differences of more than 7 years between the two $(\mathrm{p}<$ $0.001)$. Our study demonstrate a significant relation between age at onset and sex distributin in RA patients: a F:M ratio of 27.6:1 in the group of early onset $R A$ patients (age $\leq 40$ years) versus a F:M ratio of 3.55:1 for patients late onset of the disease (age $\geq$ 70 years).

The analysis of sex distribution according to age at onset in CATCH cohort (Canadian Early Arthritis Cohort) which included patients with early rheumatoid arthritis (symptoms mean duration at initial visit was approximately 186 days) shows a decrease in the number of women with late onset of RA and consecutively a decrease of $\mathrm{F}$ :M ratio: $82.5 \%$ women in the young group with age $<42$ years (F:M ratio of 4.6:1) versus $63.9 \%$ in the study group with late onset, age $>63$ years (F:M ratio of 1.75:1) (20).

A Swedish clinical trial which focused on the age at onset of RA also emphysize a lower percentage of 
women with late onset: $75.9 \%$ women (with a F:M ratio of 3.1:1) in cases with onset before age of 58 and $61.5 \%$ women (F:M ratio of $1.8: 1)$ in the group of patients with late onset (age $>58$ years) (21).

Important differences of sex ratio according age at onset are also reported in a Brasilian study: F:M ratio of 9:1 for patients with disease onset before 58 years old (age median of 45 years) compared with a F:M ratio of 3.4:1 in patients group with RA onset over age of 60 (age median of 63 years). However, this study population is a ethnic mixture (around $30 \%$ represents Negroid race)(22).

We found a decrease of F:M ratio, below 4:1, for early disease cases included in our study (56 patients) and also for those with diagnosis confirmed in the previous 5 years (110 patients). All cases with early disease are included in the group of patients with diagnosis set in the last 5 years (early disease onset after January 2012). We also found an increase of the age at onset for these cases with early disease (62.57 \pm 12.23 years) with no statistical differences between women $(62.84 \pm 12.50$ years $)$ and men (61.58 \pm 11.67 years). The age at onset in this groups of patients with early disease is 12 years later in women and 3 years later in men than the mean age at onset for the whole study group (51.71 \pm 13.67 years $)$. This change in F:M ratio could be part of the downtrend for RA incidence especially in females (23).

\section{REFERENCES}

1. Gabriel E.S., Crowson S.C. - Epidemiology of, risk factors for, and possible causes of rheumatoid arthritis. UPTODATE 2015

2. Karlson E.W., MandI L.A., Hankinson S.E. et al. - Do breastfeeding and other reproductive factors influence future risk of rheumatoid arthritis? Results from the Nurses' Health Study. Arthritis Rheum. 2004; 50(11):3458

3. Krishnan E., Sokka T. \& Hannonen P. - 2003. Smoking-gender interaction and risk for rheumatoid arthritis. Arthritis Res. Ther. 5: R158-R162;

4. De Vries N., Tak P.P., Tijssen H., et al. - Female sex increases risk for rheumatoid arthritis only in individuals encoding low-risk HLA-DRB1 alleles. Arthritis Rheum. 200348: 1762-1763)

5. Symmons D.P.M. - Epidemiology of rheumatoid arthritis: determinants of onset, persistence and outcome. Best Pract Res Clin Rheumatol 2002 16:707-722.

6. Ramos-Remus C., Sierra-Jimenez G., Skeith K. et al. - Latitude gradient influences the age of onset in rheumatoid arthritis patients. Clin Rheumatol 2007, 26:1725-1728

7. Mogosan C., Stoica V., Mihai C.M. et al. - Trends of rheumatoid arthritis monitorization in Romania, Journal of Medicine an Life Vol.3, No.3, Iulie-Septembrie 2010.

8. Cosmescu D.C., Bălănescu A., Bojincă V., Predețeanu D. Factori de risc in osteoporoza din poliartrita reumatoida. Revista Romana de Reumatologie - 2009, Vol. XVIII Nr. 4: 251-256

9. Râcă I., Bărbulescu A.L., Cojocaru-Gofiță I.R. et al. - Evaluarea osteoporozei si a riscului fracturar la pacientii cu poliartrita reumatoida - corelatii cu scorul de activitate a bolii, Revista Romana de Reumatologie - 2012, Vol. XXI, Nr. 4: 201-207

10. Popescu C., Opris D., lonescu R. et al. - Semnificatia anticorpilor Anti CCP in alte boli reumatice inflamatoare - studiu transversal, Revista Romana de Reumatologie - 2013, Vol. XXII, Nr. 3: 144-149
F:M ratio also decreases to 2:1 for smokers (ever and especially at the onset of the disease) versus non-smokers who have a F:M ratio of $14: 1(\mathrm{p}<0.001)$ by the increased risk of RA for smoker man $(\mathrm{OR}=6.58 ; 95 \%$ CI: $3.718-11.646)$. Our results are part of a subgroup analysis for smoking and sex distribution in men and women with rheumatoid arthritis. They are similar with data from other studies according to which smoking is a risk factor for RA onset in men, but not in women(3).

\section{CONCLUSIONS}

Female:Male ratio increases impresively in RA cases with early onset ( $<45$ years), young man's hormon constellation being probably a protective factor for the disease. Low socio-economical status and living in rural areas seem to increase the risk for the disease in women. F:M ratio decreases in late onset cases (3.55:1) and in smokers group by increased risk of RA in smoker man. The influence of smoking as a risk factor becomes less important in these late onset cases (age $>60$ years). Thus, patients' age, especially age at onset, seems to be the most important factor that influences sex distribution of rheumatoid arthritis.

11. Sokka T., Kautiainen H., Toloza S. et al. - (QUEST-RA): quantitative clinical assessment of patients with rheumatoid arthritis seen in standard rheumatology care in 15 countries. Ann Rheum Dis 2007; 66:1491-1496

12. Sokka T., Toloza S., Cutolo M. et al. - Women, men, and rheumatoid arthritis: analyses of disease activity, disease characteristics, and treatments in the QUEST-RA Study. Arthritis Research \& Therapy 2009, 11:R7. This article is online at: http:// arthritis-research.com/content/11/1/R7. (C) 2009 Sokka et al.; licensee BioMed Central Ltd.

13. Damjanović V., Vasilj I., Vlak T., Zelenika D. - Prevalence and risk factors of the rheumatoid arthritis in Herzegovina region in 2003-2005. Coll Antropol; 2009 Dec; 33 Suppl 2:73-7

14. Hakala M., Pöllänen R., Nieminen P. - The ARA 1987 revised criteria select patients with clinical rheumatoid arthritis from a population based cohort of subjects with chronic rheumatic diseases registered for drug reimbursement. J Rheumatol. 1993 Oct; 20(10):1674-8;

15. Hallert E., Husberg M., Kalkan A. et al. - Changes in sociodemographic characteristics at baseline in two Swedish cohorts of patients with early rheumatoid arthritis diagnosed 1996-98 and 2006-09. Scand J Rheumatol 2015;44:100-105;

16. Haugeberg G., Hansen I., Soldal D. and Sokka T. - Ten years of change in clinical disease status and treatment in rheumatoid arthritis: results based on standardized monitoring of patients in an ordinary outpatient clinic in southern Norway. Arthritis Research \& Therapy, 2015,17:219.

17. Sokka T., Kautiainen H., Pincus T. et al. - Disparities in rheumatoid arthritis disease activity according to gross domestic 
product in 25 countries in the QUEST-RA database. Ann Rheum Dis 2009; 68:1666-1672

18. Kvien K.T., Uhlig T., Ødegård S. and Heiberg S. - Marte Epidemiological Aspects of Rheumatoid Arthritis. The Sex Ratio. Ann. N.Y. Acad. Sci., 2006, 1069: 212-222.

19. Symmons D., Turner G., Webbet R. et al. - The prevalence of rheumatoid arthritis in the United Kingdom: new estimations for a new century. Rheumatology 2002;41: $793-800$.

20. Arnold B. Michael Bykerk P. Vivian, Boire Gilles et al. Are there differences between young- and older-onset early inflammatory arthritis and do these impact outcomes? An analysis from the CATCH cohort. Rheumatology 2014;53:1075 - 1086
21. Innala L., Berglin E., Möller B. et al. - Age at onset determines severity and choice of treatment in early rheumatoid arthritis: a prospective study. Arthritis Research \& Therapy 2014, 16:R94

22. Horiuchi A.C., Cardoso Pereira L.H., Kahlow Stadler B. et al. Artrite reumatoide do idoso e do jovem. Rev Bras Reumatol. 2015. http://dx.doi.org/10.1016/j.rbr. 2015.06.005

23. Doran M.F., Pond G.R., Crowson C.S. et al. - Trends in incidence and mortality in rheumatoid arthritis in Rochester, Minnesota, over a forty-year period. 2002. Arthritis Rheum. 46: 625-631). 